ISSN: 2224-0616

Int. J . Agril. Res. Innov. \& Tech. 8 (1): 7-13, June, 2018

Available online at http:// www.ijarit.webs.com

\title{
SHADING EFFECTS OF INTERCROPPING ROSELLE (Hibiscus sabdariffa) GENOTYPES ON PLANT DEVELOPMENT, ASSIMILATE PARTITIONING AND LEAF NUTRIENT CONTENT
}

\author{
M. Mataa'*, B. Makungu' ${ }^{2}$ and I. Siziya ${ }^{1}$ \\ Received 6 December 2017, Revised 28 April 2018, Accepted 26 June 2018, Published online 30 June 2018
}

\begin{abstract}
An experiment was conducted to determine the effects of shade on plant development, macronutrient and secondary metabolites in roselle (Hibiscus sabdariffa). Three roselle accessions (ZM 5729, ZM 5738 and ZM ZM5748) acquired from the Zambia National Plant Genetic Resource Centre were used and shade was imposed by intercropping roselle with maize (Zea mays). A Split plot design with shade as main plot and genotype as split- plot was used. Nutritional and development parameters were monitored. At 14 weeks shaded plants had about a three-fold decrease in branches numbers compared to unshaded ones. Plant height was higher in unshaded treatments $(120 \mathrm{~cm})$ compared to shaded $(83 \mathrm{~cm})$. Plant height of ZM 5738 was significantly higher than the other two accessions. Shading reduced dry matter aocumulation by almost $75 \%$ across genotypes with about $20 \mathrm{~g}$ per plant in shaded treatments and $73 \mathrm{~g}$ in unshaded treatments. Nutrient reductions were highest in fat (60.6 \%), fibre (48.4\%), protein (37.8\%), and lowest in ash (27.3\%). In terms of strength of partitioning the pattern was: branches $>$ leaves $>$ roots $>$ squares $>$ flowers. The carbohydrate content increased with shading (10.6\%). Vitamin C content was higher in unshaded treatments in comparison with shaded conditions. ZM 5738 had the highest content followed by ZM 5748 and ZM 5729 had the least content. Oxalates which are an anti- nutrition factor increased with shade. The findings showed that there is significant variation among genotypes and in future selections can be made to choose the most productive genotypes.
\end{abstract}

Keywords: Carbohydrates, Indigenous Vegetables, Oxalates, Proteins, Vitamin C

\footnotetext{
${ }^{1}$ School of Agricultural Sciences, Plant Science Department, PO Box 32379, Lusaka Zambia.

${ }^{2}$ Zambia Agricultural Research Institute, Plant Quarantine and Phytosanitary Unit PO Box Livingstone, Zambia.

*Corresponding author's email: mebelomataa@yahoo.com (M. Mataa)
}

\section{Introduction}

The consumption of fresh fruits and vegetables in Zambia is low particularly among the high income households (Hichaambwa et al., 2009). This low and declining consumption of fruits and vegetables is not unique to Zambia but a worldwide phenomenon (Casagrande et al., 2007; Pomerleau et al., 2004). An added complication is the declining nutritional content in new crop varieties that has been observed as plant breeders attempt to improve agronomic characteristics of crops (Simon, 2014). Consumption of vegetables and fruits can be improved by introducing and popularising 'novel' commodities. Additionally it has been suggested that improving traits readily observable by consumers (such as texture colour) rather than exclusive focus on nutritional quality may be a better approach to increasing consumption (Simon, 2014).

Growing awareness of health-promoting effects of vegetables and fruits has rekindled interest in novel or underutilised foods (Casagrande et al.,
2007; Pomerleau et al., 2004). Indigenous plants provide a cheaper and affordable source of nutrients and can play a critical role especially among the low income households (Hichaambwa et al., 2009). In Zambia one of the potentially important sources of nutrients and secondary metabolites is the indigenous vegetable, roselle (Hibiscus sabdariffa). Roselle is native to India and Malaysia, and is thought to have been introduced to Africa 6500 years ago. It is however believed to have been domesticated in Western Sudan even before 4000 B.C. (Wilson and Menzel, 1964). Many parts of the plant are of utilized with the leaves, seeds, and calyces widely used as either food or drug (FAO, 2007). Roselle is a popular vegetable in Zambia where it is commonly known as sindambi or lumanda. In addition to having high protein, carbohydrates and fibre, work done in other countries has shown the vegetable to be rich in secondary metabolites (Obouayeba et al., 2015). Secondary metabolites are biologically active phytochemicals 
usually synthesized from primary metabolites such as glucose; these compounds protect plants from environmental hazards such as pollution, stress, drought and pathogenic attacks-disease and damage (Larcher 1995; Man et al., 2011). Secondary metabolites also contribute to colour, aroma and flavour of the plant and roselle has been found to be rich in these compounds ( $\mathrm{Da}$ Costa-Rocha et al., 2014; Obouayeba et al., 2015). It is known that environmental factors such as soil $\mathrm{pH}$ and heat affect the stability of nutritional contents in many plants (Attoe and Van Elbe, 1981).

Roselle is considered to be a minor crop in the local maize-based farming systems and as a result receives less attention in terms of labour and land allocation. Commonly, roselle is intercropped with major crops such as maize (Zea mays), thus subjecting the crop to shade stress. Shade has a profound effect on plant development both through effect on light quantity (transduced through temperature effects) and light quality (photosynthesis and sensory mechanisms) (Mataa and Tominaga, 1998). There is little information on macronutrients and secondary metabolites' contents of roselle leaves under intercropping system where the light regime is altered due to shading effects by the main crop.

By definition, photo synthetically active radiation (PAR) includes wavelengths between 400 and $700 \mathrm{~nm}$ and thus, far-red radiation (FR, 700-800 $\mathrm{nm}$ ) is excluded when the photosynthetic photon flux density (PPFD) is measured. However, FR radiation and the ratio of red $(R ; 600-700 \mathrm{~nm})$ to FR regulate phytochrome-mediated morphological and developmental plant responses to promote radiation capture and survival under shade (Park and Runkle, 2017). Within a crop community, plants growing under a canopy not only experience a reduction in the amount of irradiance, but also a reduction in the quality of light as chlorophyll preferentially absorbs red (R) light and reflects far-red (FR) light. Therefore, the R : FR decreases as sunlight moves through the crop canopy (De Luca and Hungria, 2014). The decrease in the amount of $R$ light in relation to the amount of FR light thus results in an environmental cue for plants to detect neighbour plants before canopy closure (Mellendorf, 2011). That cue typically leads to a response in plant grouth. Many plant species respond to a reduction in R: FR with increased apical dominance decreased branching, increased stem extension and inter-node elongation (Mellendorf, 2011).

The objectives of this study were to (1) evaluate the effect of shade resulting from intercropping with maize on plant development and nutritional content of roselle; (2) determine whether the above effects are general or genotype dependant. It is anticipated that such information would help in further understanding of impact of cropping system on productivity of an underutilized and under researched crop and ultimately contribute to the wider cultivation and utilization of roselle.

\section{Materials and Methods}

\section{Location}

The research was conducted on Siziya farm in Ibex hill, Lusaka located in region II agroecological zone, this zone is characterized by an annual rainfall range of 800 to $1200 \mathrm{~mm}$. The site was at an altitude of about 1,279 metres, latitude $15^{\circ} 25^{\prime}$ and longitude $28^{\circ} 21^{\prime}$. Soil samples were taken and their physical and chemical properties were determined at the University of Zambia's Department of Soil Science under the School of Agricultural Sciences. The $\mathrm{pH}$ of the site was 6.05 .

\section{Plant materials}

Three local landraces of roselle were obtained from the Zambia Agricultural Research Institute, National Plant Genetic Resource Centre in Chilanga, Lusaka. The accessions of roselle were ZM 5729, ZM 5738 and ZM5748 and they were selected at random. These materials are local landraces that are grown by smallholder farmers under traditional subsistence systems. They were collected and conserved in the gene bank as normal efforts to prevent loss of genetic materials but they have not yet been characterised. A medium- maturing maize (Zea mays) variety MM 627 was used for intercropping some plots of roselle to provide shade. An early maturing maize variety was chosen so as to ensure early and continuous shade application throughout the season.

\section{Cultivation practices}

Land preparation was done as per recommended vegetable practices (Mingochi and Lucheni, 2000). Planting was done on $17^{\text {th }}$ February 2017. Three rows constituted a block and this was replicated 3 times. The centre row was used for data collection and the 2 side rows were guard rows. Weeding was done manually by hand- hoe whenever necessary. The crop depended on rainfall for water.

Fertilizer was applied as recommended for common vegetables- Basal dressing of $250 \mathrm{~kg} \mathrm{ha}^{-1}$ of a 10:20:10 analysis fertiliser (D- compound) and $120 \mathrm{~kg} \mathrm{ha}^{-1}$ urea $(46 \% \mathrm{~N})$ (Mingochi and Lucheni, 2000). Urea application was divided into two splits, with the first application (60 kg) applied at planting, and the second application at three weeks to extend the vegetative phase of the crop. The plants were monitored regularly during 
early stage days for insect damage. Common pests encountered were the cotton aphid (Aphis gossypii Glover), and Pittosporum beetles (Lamprolina impressicollis), during the early plant stages. In order to control these pests, the insecticides chlorpyrifos and cypermethrin were applied and they were effective against the aforementioned insect pests.

\section{Sample collection}

Leaf samples were collected from the centre rows. Mature roselle leaves were harvested starting at eleven weeks after planting and analyzed for moisture, ash, protein, fibre, fat and secondary metabolites. At the end of 14 week study period, 3 samples of whole plants per replicate were carefully dug up and separated into different constituent components (branches/ stems, leaves, roots reproductive structures- unopened bolls (squares) and opened flowers. These samples were dried in forced drought oven at $65^{\circ} \mathrm{C}$ for 24 hrs and dry mass was taken as described in Mataa et al. (1996).

\section{Laboratory Analyses}

Proximate analysis

Proximate analysis was done according to the AOAC (2000) which were as follows; AOAC method 934.01 for moisture; AOAC method 942.05 for ash; AOAC method 920.39 (A) for crude fat; AOAC method 984 (A-D) for crude protein; and AOAC method 978.10 for crude fibre. Total carbohydrates were calculated as follows:

Total carbohydrates $=\{100-($ ash + moisture + protein + fibre + fat) $\} \%$

Secondary metabolite analysis

Alkaloids were determined using the alkaline precipitation gravimetric method described by AOAC (2000). Oxalate content was determined using the method described by Day and Underwood (1986). The titrimetric method

967.21 was used to determine Vitamin C according to AOAC (2000).

\section{Experimental design}

A split plot design with three replications was used and consisted of shading as the main plot and the split-plots were the roselle genotypes (Sokal and Rolfe, 1981). The rows were $12 \mathrm{~m}$ in length of which one half or $6 \mathrm{~m}$ was planted with a sole crop of roselle at a $50 \mathrm{~cm}$ spacing (no shading). The other half inter-planted alternatively with maize and roselle (each at equidistant at $50 \mathrm{~cm}$ from each other). Allocation of main plot and split plot was random. The rows were spaced $1 \mathrm{~m}$ apart. Data was analyzed using GenStat 16 Software (VSN International, 2009). Where significant effects were discerned means were separated using least significant difference (LSD) test at $\mathrm{p} \leq 0.05$.

\section{Results and Discussion}

The shade exerted significant effects on plant development and secondary nutrient content, in some cases the effects were genotype specific.

\section{Plant growth (height)}

The effects of treatments on plant height are presented in Fig. 1A and Table 1. Shade reduced plant height by about $25 \%$. Plant height followed a double sigmoid pattern with an initial rapid expansion from planting up to week 6 after which growth slowed down until about week 12 when it increased again. Differences in plant height emerged at 5 weeks after planting (Fig. 1A). Plant height at 14 weeks after planting was higher in unshaded condition $(120 \mathrm{~cm})$ than in shaded $(83$ $\mathrm{cm})$. There were significant differences among genotypes. ZM 5738 accession had the fastest growth throughout the observation period and at 14 weeks it was significantly taller than the other two. Initial rapid growth was observed for ZM 5738 under shaded, although it declined towards the end. At the end of 14 weeks observation there were no significant differences among the genotypes in the shaded treatments.
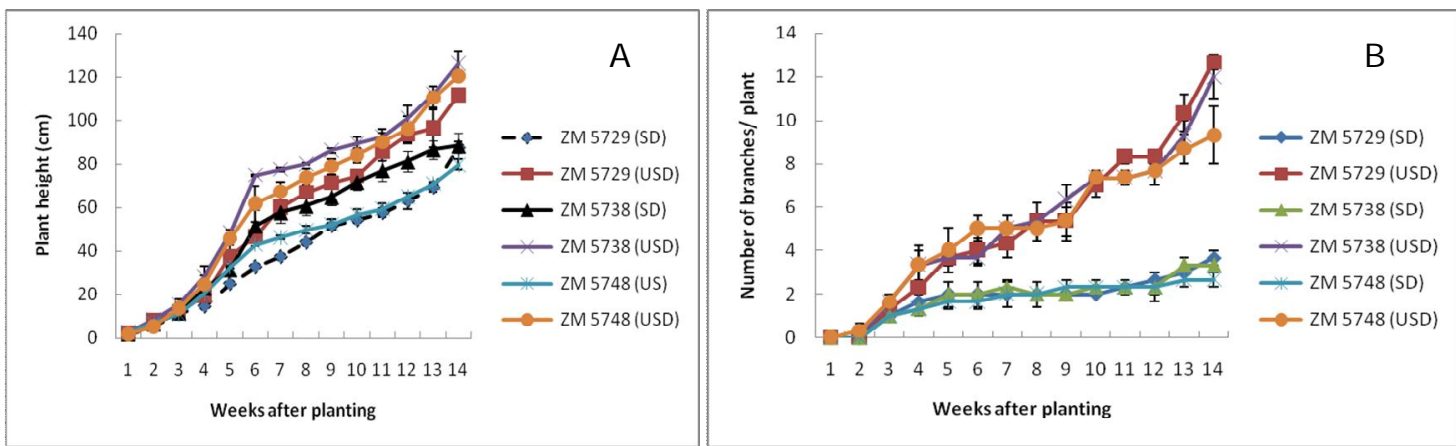

Fig 1. Changes in plant height (A) and number of branches per plant (B) among three roselle accessions subjected to shading by maize intercrop. SD (shaded) and USD (unshaded) treatments. 


\section{Branching}

Fig. 1B shows the effect of shading on number of branches of the genotypes across the growth period. The branching pattern was similar to the one for plant growth. Shade reduced branching significantly. At 14 weeks after planting shaded plots had 3.2 branches compared to 11 for unshaded ones. Branching increased with age in all accessions and there were highly significant interactions $(p<0.001)$ between shading, age and the genotypes. ZM 5738 had significantly taller plants but less branching under shaded and unshaded conditions. In contrast, ZM 5729 had significantly more branching under shade compared to the other two accessions.

Dry matter partitioning

The effects of treatments on the dry matter content are shown on Table 1. There was a very significant effect of shading $(p<0.02)$ on the total dry matter content of the different genotypes. Shading reduced dry matter accumulation by almost $75 \%$ across genotypes with about $20 \mathrm{~g}$ plant-1 in shaded treatments and $73 \mathrm{~g}$ in unshaded treatments. In terms of strength of assimilate partitioning, it was: branches > leaves $>$ roots $>$ squares $>$ flowers. Partitioning to branches, flowers (opened) and roots was not influenced by either shade or genotype but to leaves and squares it was influenced by shading. Highly significant shade and genotypic effects were observed in squares. Partitioning to leaves was reduced by shading (Table 1). Shaded plots had $20 \%$ of DM partitioned to leaves whereas unshaded ones partitioned close to $30 \%$ of DM to leaves. Contrarily, shading partitioned $20 \%$ of their DM to reproductive structures and unshaded plots partitioned $\approx 8 \%$. There were significant differences among genotypes ZM 5748 partitioned significantly more DM to reproductive structures (squares) than the other two accessions ( $p=01)$. De Luca and Hungria, (2014) noted that there is a reduction in the quality of light as sunlight moves through the crop canopy because chlorophyll preferentially absorbs red (R) light and reflects far-red (FR) light, thereby the $\mathrm{R}$ : FR decreases. It can therefore, be postulated that the observed morphological responses were due to changes in light quality arising from shade.

\section{Macronutrients}

The effects of treatments (shading effect on genotypes) on macronutrients (ash, carbohydrate, protein, fibre, moisture and fat) content are presented in Table 2.

Table 1. Effect of shading on dry matter (DM) partitioning in selected Roselle (Hibiscus sabdariffa) accessions.

\begin{tabular}{|c|c|c|c|c|c|c|c|}
\hline \multirow[t]{2}{*}{ Factors } & \multirow[t]{2}{*}{ Genotype } & \multirow{2}{*}{$\begin{array}{c}\text { Total } \\
\text { DM (g) }\end{array}$} & \multicolumn{5}{|c|}{ Dry matter partitioning (\%) } \\
\hline & & & Branches & Flowers & Roots & Leaves & Squares \\
\hline \multirow{3}{*}{ Shade } & Shaded & 19.60 & 46.84 & 3.02 & 10.31 & 20.37 & 20.35 \\
\hline & Unshaded & 73.10 & 48.81 & 4.56 & 9.42 & 28.80 & 7.52 \\
\hline & LSD & 35.10 & 9.31 & 4.15 & 5.55 & 7.04 & 12.09 \\
\hline \multirow{4}{*}{ Genotype } & ZM 5729 & 51.80 & 50.99 & 2.95 & 9.77 & 25.09 & 11.20 \\
\hline & ZM 5738 & 47.20 & 45.58 & 5.34 & 10.23 & 25.81 & 13.04 \\
\hline & ZM 5748 & 40.20 & 46.91 & 3.09 & 9.60 & 20.37 & 17.56 \\
\hline & LSD & 13.28 & 12.52 & 4.26 & 4.74 & 10.63 & 3.62 \\
\hline \multicolumn{8}{|c|}{ Shade X Genotype } \\
\hline \multirow{3}{*}{ Shaded } & ZM 5729 & 23.80 & 51.30 & 3.12 & 11.04 & 18.15 & 16.40 \\
\hline & ZM 5738 & 19.50 & 45.66 & 5.23 & 7.23 & 23.80 & 18.27 \\
\hline & ZM 5748 & 15.60 & 43.76 & 0.71 & 9.98 & 19.17 & 26.37 \\
\hline \multirow{4}{*}{ Normal } & ZM 5729 & 79.90 & 50.68 & 2.77 & 8.50 & 32.04 & 6.01 \\
\hline & ZM 5738 & 74.80 & 47.71 & 5.45 & 13.43 & 27.81 & 7.80 \\
\hline & ZM 5748 & 64.80 & 50.05 & 5.46 & 9.98 & 21.45 & 8.75 \\
\hline & LSD & 27.07 & 14.89 & 5.22 & 6.02 & 12.54 & 9.43 \\
\hline \multicolumn{8}{|c|}{ Factor effects ( $p$ values) } \\
\hline \multirow{2}{*}{\multicolumn{2}{|c|}{$\begin{array}{l}\text { Main (Shade) } \\
\text { Split (Gno) }\end{array}$}} & 0.02 & 0.46 & 0.25 & 0.56 & 0.04 & 0.05 \\
\hline & & 0.19 & 0.60 & 0.39 & 0.95 & 0.80 & 0.01 \\
\hline \multicolumn{2}{|c|}{ Shade X Genotype } & 0.81 & 0.79 & 0.37 & 0.15 & 0.56 & 0.08 \\
\hline
\end{tabular}

Treatment Effects: < 0.001 (Very highly significant), <0.01 (highly significant), <0.05 (significant), > 0.05 (not- significant)

All the nutritional components were highly affected by shade and there were highly significant genotype $\mathrm{x}$ shade interactions $(\mathrm{p}<$ 0.001) except for ash and fibre. Shade significantly reduced fibre, fat and protein content. The reductions were fat (60.6\%), fibre $48.4 \%$ ), and protein (37.8\%). Carbohydrate content increased with shading (10.6\%). 
Table 2. Effect of shading on compositional factors in selected Roselle (Hibiscus sabdariffa) accessions.

\begin{tabular}{|c|c|c|c|c|c|c|}
\hline \multirow[t]{2}{*}{ Factors } & \multirow[t]{2}{*}{ Genotype } & \multicolumn{5}{|c|}{ Compositional factors (\%) } \\
\hline & & Ash & Fibre & $\mathrm{CHO}$ & Fat & Protein \\
\hline \multirow{3}{*}{ Shading } & Shaded & 4.70 & 2.90 & 80.12 & 0.84 & 8.23 \\
\hline & Unshaded & 6.60 & 5.62 & 72.42 & 2.13 & 13.23 \\
\hline & LSD & 0.15 & 0.26 & 3.49 & 0.11 & 0.78 \\
\hline \multirow{4}{*}{ Genotype } & ZM 5729 & 4.82 & 4.10 & 78.12 & 1.54 & 11.11 \\
\hline & ZM 5738 & 6.60 & 4.41 & 75.29 & 1.58 & 9.79 \\
\hline & ZM 5748 & 5.53 & 4.27 & 75.40 & 1.33 & 11.30 \\
\hline & LSD & 0.25 & 0.26 & 3.46 & 0.13 & 1.21 \\
\hline \multicolumn{7}{|c|}{ Shadex Genotype } \\
\hline \multirow{3}{*}{ Shaded } & ZM 5729 & 3.76 & 2.76 & 83.95 & 0.74 & 8.17 \\
\hline & ZM 5738 & 5.61 & 3.41 & 79.79 & 1.08 & 8.45 \\
\hline & ZM 5748 & 4.74 & 2.52 & 79.61 & 0.70 & 8.07 \\
\hline \multirow{4}{*}{ Normal } & ZM5729 & 5.88 & 5.44 & 72.28 & 2.35 & 14.04 \\
\hline & ZM 5738 & 7.59 & 5.41 & 73.79 & 2.08 & 11.13 \\
\hline & ZM 5748 & 6.32 & 6.02 & 71.18 & 1.95 & 14.52 \\
\hline & LSD & 0.21 & 0.19 & 2.62 & 0.11 & 0.70 \\
\hline \multicolumn{7}{|c|}{ Factor significance ( $\mathrm{p}$ values) } \\
\hline \multirow{2}{*}{\multicolumn{2}{|c|}{$\begin{array}{l}\text { Main (Shade) } \\
\text { Split (Genotvme) }\end{array}$}} & $<0.001$ & $<0.001$ & 0.01 & $<0.001$ & $<0.001$ \\
\hline & & $<0.001$ & 0.02 & 0.06 & $<0.001$ & $<0.001$ \\
\hline \multicolumn{2}{|c|}{ Shade x Genotype } & 0.05 & $<0.001$ & 0.02 & $<0.001$ & $<0.001$ \\
\hline
\end{tabular}

Treatment Effects: < 0.001 (very highly significant), <0.01 (highly significant), $<0.05$ (significant), > 0.05 (not- significant)

Macronutrients are synthesized through different Baker, 1967; Mohr and Schopfer, 1994). Daily respiratory pathways from carbon skeletons patterns of net photosynthesis in most plants derived from photosynthetic products (Mohr and follow irradiation levels (Tenhunen et al., 1989; Schopfer, 1994; Lehninger et al., 1983). The Hesketh and Baker, 1967; Larcher, 1995). It is Calvin - Benson cycle through which assimilates generally accepted that shade in a multi- storey are synthesized is dependent on availability of cropping systems will reduce light for lower lying photo synthetically active radiation which is low plants (Hesketh and Baker, 1967). when plants are grown under shade (Hesketh and

Table 3. Effect of shading on secondary metabolite content in selected Roselle (Hibiscus sabdariffa) accessions.

\begin{tabular}{|c|c|c|c|}
\hline \multirow[t]{2}{*}{ Factors } & \multirow[t]{2}{*}{ Genotype } & \multicolumn{2}{|c|}{ Compositional factors (\%) } \\
\hline & & Vitamin C & Oxalate \\
\hline \multirow{3}{*}{ Shading } & Shaded & 85.14 & 3.68 \\
\hline & Unshaded & 300.77 & 1.37 \\
\hline & LSD & 4.30 & 0.16 \\
\hline \multirow{4}{*}{ Genotype } & ZM5729 & 186.54 & 3.00 \\
\hline & ZM5738 & 207.38 & 2.56 \\
\hline & ZM5748 & 184.95 & 2.03 \\
\hline & LSD & 4.86 & 0.39 \\
\hline \multicolumn{4}{|c|}{ Shade x Genotype } \\
\hline \multirow{3}{*}{ Shaded } & ZM 5729 & 88.64 & 4.45 \\
\hline & ZM 5738 & 92.45 & 3.85 \\
\hline & ZM 5748 & 74.33 & 2.72 \\
\hline \multirow{4}{*}{ Normal } & ZM 5729 & 284.45 & 1.54 \\
\hline & ZM 5738 & 322.31 & 1.25 \\
\hline & ZM 5748 & 295.56 & 1.34 \\
\hline & LSD & 5.80 & 0.45 \\
\hline \multicolumn{4}{|c|}{ Factor significance (p values) } \\
\hline \multicolumn{2}{|c|}{ Main (Shade) } & $<0.001$ & $<0.001$ \\
\hline \multicolumn{2}{|c|}{ Split (Genotype) } & $<0.001$ & $<0.002$ \\
\hline \multicolumn{2}{|c|}{ Shade x Genotype } & $<0.001$ & 0.005 \\
\hline
\end{tabular}

Treatment Effects: <0.001 (very highly significant), <0.01(highly significant), > 0.05 (not- significant) 


\section{Ash content}

There was a highly significant difference $(\mathrm{p}<$ 0.001) of the ash content of the leaves across the three genotypes at mature stage under different shading conditions. And the shading effect on ash content was higher in unshaded conditions with genotype ZM 5738 having the highest content followed by ZM 5748 and ZM 5729 had the lowest content. Ash is principally made of soil derived minerals which the plant integrates into its own bio-molecules and any process that reduces availability of energy (derived from photosynthesis) necessary for metabolic activities and nutrient absorption will ultimately reduce mineral uptake and ash content.

\section{Vitamin C content}

Ascorbic acid also known as vitamin $\mathrm{C}$ is a watersoluble vitamin and essential nutrient that supports growth and development in humans. There was a highly significant difference $(p<$ 0.001 ) in the Vitamin C content of mature leaves across the three accessions of roselle under different shading conditions. The Vitamin C content was higher in normal (un-shaded) treatments in comparison with shaded treatments. ZM 5738 had the highest content followed by ZM 5748 and ZM 5729 had the least content. Vitamin $\mathrm{C}$ is the most abundant of the antioxidants found in plants and its biosynthetic pathway is from glucose via guanosine diphosphate mannose (GDP-D-mannose) and Lgalactose (Conklin et al., 1994; Keller et al., 1999). It is also important in the regulation of iron uptake, stabilizing iron-binding proteins and encouraging the absorption of non-haeme iron into the gastrointestinal tract (Hacişevki, 2009).

\section{Oxalate content}

There was a highly significant difference $(\mathrm{p}<$ 0.001 ) in the oxalate content of mature leaves across the three accessions of roselle under different shading conditions. The oxalate content was higher in shaded conditions with ZM 5729 recording the highest content followed by $\mathrm{ZM}$ 5738 and ZM 5748 had the least content. Oxalic acid and its salts occur as end products of metabolism in several plant tissues (Hitomi et al., 1992). It has been suggested that the accumulation of oxalate in plant tissues is attributed to a shift in equilibrium towards biosynthesis rather than to degradation (Hitomi et al., 1992). For instance oxalate concentration in spinach (Brassica spp.) leaves decreased with time in cultivars with rapid growth rates than it did in those with slow growth rates, indicating that oxalate may be necessary and used in plant growth (Hirooka and Sugiyama, 1992). We found that oxalates were higher in shaded treatments which were also slow growing as they were shorter and had less branching. This is in agreement with the findings of Hirooka and Sugiyama (1992). From human nutritional perspective, high oxalate content is undesirable as it increases risk of medical conditions such as bladder stones.

\section{Conclusion}

The results indicated that the three accessions contain substantial amount of the desired nutrients and secondary metabolites. The study confirmed that local accessions have appreciable amounts of carbohydrates, fats, proteins, fibre, fats, ash as well as vitamin $\mathrm{C}$, oxalate and total phenolics. Additionally there is significant variation among genotypes and in future selections can be made to choose the most productive genotypes. However, intercropping of the plant which is common among small scale growers is undesirable as it reduced both plant productivity and nutritional content.

\section{Acknowledgement}

We are grateful to the Feed the Future Innovation Lab for Collaborative Research on Horticulture (USAID, UC Davies) for financial support and to the Zambia National Genebank for providing the Rosellelandraces.

\section{References}

AOAC. 2000. Method 967.21. Official methods of analysis, $18^{\text {th }}$ ed., Gaithersburg MD: AOAC International. p. 33.

Attoe, L. and Van Elbe. 1981. Effects of blanching and freezing on the structure of carrots cells and their implications for food processing. J . Sci. Food Agric. 77: 223-229.

Casagrande, S.S., Wang, Y., Anderson, C. and Gary, T.L. 2007. Have Americans increased their fruit and vegetable intake? The trends between 1988 and 2002. American J. Prev. Med. 32: 257- 293.

Conklin P.L., Pallanca J. E., Last. R.L., Smirnoff N. 1994, L-Ascorbic acid metabolism in the ascorbate-deficient Arabidopsis mutant vtc1. Plant Physiol. 115: 1277-1285.

Da-Costa-Rocha, I., Bonnlaender, B., Sievers, H., Pischel, I. and Heinrich, M. 2014. Hibiscus sabdariffa L. A Phytochemical and Pharmacological Review. Food Chem. 165: 424- 443.

Day, R.A. and Underwood, A.L. 1986. Quantitative Analysis, 5th ed., London: Prentice Hall. p. 701.

De Luca, M.J. and Hungria, M. 2014. Plant densities and modulation of symbiotic nitrogen fixation in soybean. Scientia Agricola. 71: 181-187. 
FAO. 2007. Hibiscus sabdariffa var. sabdariffa, Factsheet. Rome: Food and Agriculture Organization of the UN. pp. 1-2.

Hacişevki, A. 2009. An Overview of ascorbic acid biochemistry. J. Fac. Pharm. Ankara Univ. 38: 233-255.

Hesketh, J . and Baker, D. 1967. Light and carbon assimilation by plant communities. Crop Sci. 7: 285- 293.

Hichaambwa, M., Beaver, M. Chapoto, A. and Weber, M. 2009. National Food and Nutrition Commission. National surveillance report: Key nutrition indicators by district, Zambia. Food Security Research Project. Working Paper No. 43.

Hirooka, M. and Sugiyama, N. 1992. Effect of growth rates on oxalate concentrations in spinach leaves. J. J pn. Soc. Hort. Sci. 61: 575- 579 .

Hitomi, E., Tamaki, Y. and Tomoyeda, M. 1992. Biogenesis and degradation of oxalate in spinach. J. J pn. Soc. Hort. Sci. 61: 431- 435.

Keller, R., Springer, F., Renz, A. and Kossmann, J. 1999. Antisense inhibition of the GDPmannose pyrophosphorylase reduces the ascorbate content in transgenic plants leading to the developmental changes during senescence. Plant J. 19: 131-141.

Larcher, W. 1995. Physiological plant ecology: Ecophysiological plant ecology. Springer. pp. 74- 128.

Lehninger, A.L., Nelson, D.L. and Cox, M.M. 1983. Principles of Biochemistry. New York. Worth Publishers. pp. 599- 686.

Man, D., Bao, Y. and Han. 2011. Drought tolerance associated with proline and hormone metabolism in two tall Fescue cultivars Hort. Sci. 46: 1027-1032.

Mataa, M. and Tominaga. S. 1998. The Effects of shading stage and level on fruit set and development, leaf carbohydrates and photosynthesis in ponkan (Citrus reticulata Blanco). Japan. J. Trop. Agric. 42: 103- 110.

Mataa, M., Tominaga, S. and Kozaki, I. 1996. Seasonal changes of carbohydrate constituents in ponkan (Citrus reticulata Blanco). J . J pn. Soc. Hort. Sci. 65: 513- 523.

Mellendorf, E.N. 2011. Soybean growth and yield response to interplant competition relief in various plant density environments. MSc. Thesis, University of Illinois at UrbanaChampaign. pp. 11-12.

Mingochi, D.S. and Lucheni, S.W. 2000. Improved vegetable practices for smallholder farmers in Zambia: A reference manual for field extension workers. Field document No. 1. FAO and Ministry of Agriculture, Food and Fisheries. Lusaka, Zambia. pp. 15-17.

Mohr, H. and Schopfer, P. 1994. Plant physiology. Springer. pp. 148- 166.

Obouayeba, A.P., Diarrassouba, M., Soumahin, E.F. and Kouakou, T.H. 2015. Phytochemical analysis, purification and identification of Hibiscus anthocyanins. J. Pharma. Chem. Biol. Sci. 3: 156- 168.

Park, Y. and Runkle, E.S. 2017. Far-red radiation promotes growth of seedlings by increasing leaf expansion and whole- plant net assimilation. Environ. Exp. Bot. 136: 41- 49.

Pomerleau, J., Lock, K., Kenai, C. and McKee. M. 2004. Effectiveness of interventions and programmes promoting fruit and vegetable intake. World Health Organization. Background paper for the joint FAO/WHO Workshop on fruit and vegetables for health. 1-3 September 2004, Kobe, J apan. pp. 1-2.

Simon, P.W. 2014. Progress towards increasing intake of dietary nutrients from vegetables and fruits: The case for greater role of horticultural sciences. Hort. Sci. 49: 112- 115.

Sokal, R.R. and Rolfe, F.J. 1981. Biometry, Second edition. W.H. Freeman and Company, New York. pp. 394- 399.

Tenhunen, J.D., Reynolds, J.F., Longe, O.L., Dougherty, R.L., Harley, P.C., Kummerow, J . and Rambal, S. 1989. Quinta; a physiologically based growth simulator for drought adapted woody plant species. In: Perira, J.S. and J.J. Landsberg (eds) Biomass production by fast growing trees. Kluwer, Dordrecht. pp. 135- 168.

VSN International, 2009. Numerical Algorithms Group. www.nag.co.uk

Wilson, F.D. and Menzel M.Y. 1964. Kenaf (Hibiscus cannabinus), roselle (Hibiscus sabdariffa), Econ. Bot. 18: 80- 91. 